Article

\title{
The Perceived Role of Financial Incentives in Promoting Waste Recycling-Empirical Evidence from Finland
}

\author{
Beatrice Abila * and Jussi Kantola \\ Department of Industrial Management, Faculty of Technology, University of Vaasa, PO Box 700, \\ 65101 Vaasa, Finland; jussi.kantola@uva.fi \\ * Correspondence: bobule@uva.fi
}

Academic Editor: Giovanni De Feo

Received: 15 November 2018; Accepted: 28 December 2018; Published: 10 January 2019

\begin{abstract}
Placing emphasis on promoting the reduction, reuse, recycling, recovery and repair of waste has been a critical aspect of the sustainable waste management agenda. Considering recycling, an environmentally friendly and sustainable waste management option, monetary rewards are in place for certain recyclable municipal waste materials in Finland. The study investigates consumers' perception about the role of financial incentives in effecting the recycling of municipal solid waste materials in Finland. The study also considers drivers for recycling municipal solid waste on the basis of behavioural change factors, such as environmental risk, behavioural economics, resource value, economic benefit, convenience, knowledge, legislation and belief. It further determines the association between income-earning consumers and non-income-earning consumers in their perception of financial incentives for recycling. The empirical results from the study confirm that the role of financial incentive is important in accelerating the recycling of municipal solid waste. A weak-to-positive relationship exists between drivers for recycling municipal solid waste and recycling behaviour. There exists no statistically significant difference in the means of the perceived role of financial incentives for recycling in the two groups. The introduction of financial incentives for other recyclable wastes is required in order to boost consumers' participation in the recycling of municipal solid waste. The need to pay more attention to intrinsic and extrinsic factors, as they affect the participation members of the society in the recycling of municipal solid waste, is paramount. This has become necessary in ensuring sustainable waste management in Finland.
\end{abstract}

Keywords: financial incentives; behaviour change; recycling; waste management; Finland; consumer perception; sustainable waste management

\section{Introduction}

The quest for attaining sustainable waste management has led to the creation of a waste hierarchy. This waste hierarchy, which provides a classification of waste management into different management options, is based on the benefits for, as well as welfare and interests of, the environment, society and the economy. These management options, which in some countries have evolved into strategies relating to process, infrastructure, legislation and stakeholders, among others, include the five Rs of waste management. These five Rs-reduce, reuse, recycle, recovery and repair-are increasingly important for attaining sustainable waste management [1]. The efficient application of strategies emanating from the five Rs is taking place via different methods. Key among the methods is motivating different stakeholders in the waste management or generation chain to participate responsibly in attaining efficient waste management goals. Examples include executing campaigns or advocacy programmes for citizens, establishing knowledge forums for waste experts, initiating workshops and seminars 
for waste managers, job satisfaction and promotion of workers in waste management companies, and providing monetary incentives for recyclables.

In developed countries, research on waste recycling focuses on technical applications (such as models and tools), policy analysis (such as command-and-control, social-psychological and economic incentives) and, to a great extent, the psychological and socio-economic influence on human behaviour [2]. In attaining the goals of minimizing the proportion of waste which enters the waste management chain, and indeed the proportion and composition of waste finally disposed in landfills, key stakeholders within the waste management chain in different countries have implemented various tools, such as waste information and sorting guides, and waste and recycling apps and labels. These tools help in increasing the sensitization of households, such that they can make informed decisions on the implementation of the five Rs in the case of municipal solid waste, determining what is considered waste, what is disposed of in kerbside containers, and what is taken to reverse vending machines, among others. Aside from these tools, other strategies include providing financial incentives for households to participate in the recycling, reuse or recovery of waste. In most countries, reward, penalty and pricing standards for several types of waste materials, including packing materials, plastics, glass bottles and cans, already exist. Accordingly, Reference [3] reported on the implementation of a scheme known as "pay as you throw" (PAYT), a reward process for particular waste items which are disposed of in designated recycling sheds or centres. This reward and pricing system is currently being implemented for drink containers in Finland, particularly containers of soft and alcoholic drinks.

In attaining the sustainable management of waste, there is a tendency towards implementing recycling drivers, such as monetary incentives, consequences, proximity to recycling facilities, to influence consumers' recycling behaviour. The extent of recycling drivers instituted may enhance consumer behaviour, which in turn affects the recycling rate. Therefore, in essence, consumer behaviour and recycling drivers are not mutually exclusive.

Considering the significant benefits derived from recycling waste, particularly by striving towards a circular economy, EU countries are expected to recycle 50\% of their municipal waste by 2020 [4], as well as achieve of target of $65 \%$ for recycling municipal waste by 2030 [5]. In the case of Finland, the municipal solid waste recycling rate substantially lies far behind these targets, at $41 \%$ [6].

The quantity of municipal waste has been 2.4 to 2.8 million per year in Finland since the turn of the millennium [7], while growing to around 2.9 million tonnes in 2016 [8]. The Finnish municipal solid waste management systems are mainly based on source separation and separate collections of recoverable waste fractions [6]. In Finland, households are responsible for the primary management of municipal solid waste, which involves the sorting, packaging and disposing of municipal solid waste into kerbsides containers, the delivery of certain household waste items to waste management companies, as well as the deposition of polyethylene terephthalate (PET) plastic bottles, glass bottles and drink cans into reverse vending machines, all of which constitutes a major consumer service [9]. On the other hand, property owners are obliged to organize waste collection points for household waste, while municipal authorities usually organize waste transportation through agreements with private waste companies, as well as mandated to organize the utilization and treatment of the waste they are responsible for [10].

This study investigates consumers' perception about the role of financial incentives for executing the recycling of municipal solid waste in Finland. Specifically, the study aims to determine the relationship between consumers' perception about financial incentives for recycling and recycling behaviour as well as drivers for recycling and recycling behaviour. The study also ascertains the key motivational factors behind recycling and determines the association between the perception of income-earning consumers and that of non-income-earning consumers concerning financial incentives for recycling.

This study centres on the PAYT scheme as a system of financial incentives, as it is the only system of this kind available for the management of municipal solid waste and more directly aligned to facilitating the recycling of specified municipal solid waste in Finland. 
This paper comprises the following sections: Section 2 reviews the literature on PAYT schemes, Section 3 discusses the materials and methods applied in the study, Section 4 presents the results and discussion, and Section 5 highlights the conclusions and makes recommendations based on the study.

\section{Literature Review-PAYT Schemes}

In recent years, different waste management schemes, such as waste disposal fee and PAYT schemes, have been introduced and implemented to promote the management of solid waste across the globe [11]. In Europe, the German city of Dresden was the first to launch an electronic identification and pricing system for the billing of waste charges [12]. Likewise, Austria was the first country to commence the implementation of the principle of individual waste charging, as far back as 1945, although significant advances in applying PAYT did not begin until the 1980s [13,14]. The city of San Francisco in the US also practised a kind of PAYT scheme from 1932 [13]. Similar to the PAYT scheme, various financial incentive schemes have been implemented in most developed countries to facilitate recycling. PAYT is a strategy in which consumers are provided economic incentives to decrease the waste they discard [15]. It plays a non-simultaneous dual role in terms of rewards and penalties, encouraging consumers to adapt to waste management policies put in place.

PAYT schemes are common practices in most European countries, with Spain being one of the few exceptions. The growth of PAYT in Europe has prompted Spain to take a step toward the adoption of variable charging $[16,17]$. In France and Ireland, waste policies were recently revised to allow for the consideration of PAYT for municipal waste [13]. In France, the current investigation has identified between 14 and 20 local authorities committed to the application of incentive fees, whereas, in 2001, seven local authorities were identified [18]. In the US, PAYT has led to an increasing rate of recycling and a mean reduction rate of $28 \%$ for landfilled waste [19]. In Japan, 954 municipalities had implemented PAYT for residential combustible waste and 686 for residential incombustible waste as of 2003 [20]. Several other countries, including Australia, Canada, the UK and Mexico, have also introduced PAYT programmes [20]. Similarly, in Finland, the recycling policy in place for certain municipal solid waste items is a PAYT scheme, which has been adopted to ensure recyclables are properly disposed of. That said, the PAYT scheme is limited to PET plastic bottles, drink cans and glass bottles in Finland. It is fundamental to increase recycling in Finland, considering that its high domestic material consumption (DMC) per person is about 39.3 tonnes per annum [9]. Moreover, it is pertinent to increasingly adopt recycling, which is a more environmentally friendly disposal option, apart from its economic benefits in terms of limiting the costs of purchasing virgin materials and saving energy [21], as well as the economic benefits of reducing processing costs. In addition, recycling is socially beneficial because it generates jobs, both directly and indirectly [22].

There are different research contributions on incentives for recycling municipal solid waste across the globe. A study conducted in Reference [23] discussed a new market-incentive recycling system for packaging waste in Taiwan. Reference [24] also examined the willingness to accept economic incentives for solid waste in Ghana. An empirical study conducted in Reference [25] assessed the potential of financial incentives to enhance recycling behaviour in the UK. Moreover, Reference [21] investigated an incentive scheme in Hong Kong in order to determine whether it has worked in promoting domestic waste recycling. Evidence from the literature confirms that various efforts and strategies have been adopted in different countries to enhance the recycling of waste. This study aims to provide empirical evidence that monetary incentives for recycling play critical roles in the actualization of the goal of waste management in Finland.

\section{Methodology}

The study was carried out in Vaasa, a municipality on the west coast of Finland. Data for the study were collected from five higher institutions, namely, the University of Vaasa, Vaasa University of Applied Science, Novia University of Applied Science, Abo Akaedemi University and Hanken School of Economics. A cluster sampling technique was used to obtain a representative sample for the 
study. This technique refers to a group of population elements, which constitutes the sampling unit. The sampling unit for this study comprises the aforementioned higher institutions in Vaasa.

A structured questionnaire was designed to elicit information on the perceived role of financial incentives in promoting waste recycling in Finland. The questionnaire was explicitly written in a simple format of close-ended questions, consisting of both categorical and ordinal variables. The ordinal variables were ranked on a five-point Likert scale, as follows: strongly agree $=1$, agree $=2$, undecided $=3$, disagree $=4$, strongly disagree $=5$. A number of studies was reviewed to develop questions related to the role of financial incentives for recycling, as well as questions focusing on drivers for recycling. Questions regarding the perceived roles of financial incentives for recycling were listed for respondents to score on the five-point Likert scale. These statements considered the roles of financial incentive, such as stimulating knowledge for the recycling of waste, waste reduction and increased recycling. Other roles considered were behavioural change, critical motivational factors for recycling, influencing the desire to recycle waste, influencing current positive trends for recycling waste, tangible benefits for recycling waste, feasible goals for recycling waste, a sustainable approach for recycling waste, raising awareness for recycling waste, and promotion of recycling best practices.

Subsequently, questions focusing on drivers for recycling were listed, reflecting behavioural change drivers, including: Environmental risk, behavioural economics, resource value, economic benefit, convenience, knowledge, legislation and belief. Furthermore, questions bordering on recycling behaviour pertaining to various types of recyclable waste were also asked, in order to be rated on the five-point Likert scale.

A face-to-face interview was adopted for administering the questionnaires to 123 respondents. All 123 questionnaires were administered to students and staff across the five higher institutions located in Vaasa.

The first section of the questionnaire included questions focusing on the personal characteristics of respondents, while subsequent sections of the questionnaire included questions centred on the role of financial incentives for recycling from consumers' perspective, motivational factors for recycling and recycling behaviour. The data collected from the survey were analysed using the Statistical Package for Social Science (SPSS) software, version 24 (IBM Corporation, Armonk, UY, USA). Both descriptive (frequency table, percentage, mean and standard deviation) and inferential statistics (Spearman's rank-order correlation and $t$-test) were used to analyse the data.

The frequency table is used to display the number of times an event or characteristics occurred in this study. Percentage is also adopted for displaying explicit differentiation and analysis. Standard deviation is used to indicate the extent of variability. The mean is used as a measure of central tendency. Furthermore, the choice of Spearman's rank-order correlation in this study is made on the basis that it is the appropriate statistical method for determining the strength and direction between two variables at the ordinal level. The $t$-test is the applicable statistical method for determining whether there is a significant difference in the mean of two groups.

\section{Results and Discussion}

\subsection{Descriptive Statistics}

\subsubsection{Socio-Economic Characteristics}

The socio-economic status of the respondents is shown in Table 1. In the study, more than one third of the participants are male (41.5\%), while more than half are females (58.5\%). It is also worthy of note that females constitute the highest proportion of shoppers, as this reflects the gender roles of housekeeping and family care, among others [26]. More than $87 \%$ of the respondents are single. Further analysis will help to assess how the marital status of respondents is reflected in their response to incentives for recycling. $71.0 \%$ of the respondents have completed tertiary education. A study on the adaptation of environmental anticipation in the case of an educational computer game in Reference [27] identified knowledge as a key driver for influencing participation in recycling. Approximately half of 
the participants earn income (49.6\%). Most of the respondents (82.1\%) fall within the age interval of 20-29 years.

Table 1. Socio-economic characteristics of respondents.

\begin{tabular}{cccc}
\hline & Category & Frequency & Percentage \\
\hline \multirow{2}{*}{ Sex } & Male & 51 & 41.5 \\
& Female & 72 & 58.5 \\
\hline \multirow{3}{*}{ Marital status } & Single & 108 & 87.8 \\
& Married & 14 & 11.4 \\
& Widow & 1 & 0.8 \\
& Widower & - & - \\
\hline \multirow{4}{*}{ Educational level } & High school & 48 & 39.0 \\
& Bachelor & 54 & 43.9 \\
& Master & 14 & 11.4 \\
& Doctor & 7 & 5.7 \\
\hline \multirow{2}{*}{ Age in years } & $20-29$ & 101 & 82.1 \\
& $30-39$ & 17 & 13.8 \\
& $40-49$ & 5 & 4.1 \\
Earned income & 50 and above & - & - \\
Non-earned income & Yes & 61 & 49.6 \\
\hline
\end{tabular}

\subsubsection{Perceived Role of Financial Incentives for Recycling}

The results in Table 2 indicate the perceived role of financial incentives for the recycling of municipal solid waste on a five-point Likert scale in the range from strongly agree (1) to strongly disagree (5). See Table 3 for the variables and definitions of the perceived role of financial incentives for recycling.

More than half $(62.6 \%)$ of the participants agreed that financial incentive is the main consideration in the case of behavioural change, while $52.8 \%$ of the participants agreed that financial incentive stimulates knowledge for recycling waste. About one third (38.2\%) of the participants agreed that financial incentive is a tangible benefit for recycling waste. Less than one quarter $(24.4 \%)$ of the participants disagreed that financial incentive is a critical motivational factor for recycling, while $19.5 \%$ of the participants strongly agreed that financial incentive influences the desire to recycle waste.

The findings from the survey of consumers on the perceived role of financial incentives for the recycling of municipal waste show that effecting behavioural change (mean rank $=2.20$ ) is the major outcome. This infers that financial incentives are crucial towards leveraging existing behavioural patterns and perceptions for increasing the recycling of municipal solid waste. This result agrees with the findings of Reference [28], which found that financial incentives can promote pro-environmental behaviour and contribute to sustained behaviour. Likewise, the minor role is that financial incentive is a tangible benefit for recycling $(\mathrm{M}=2.58)$. The hierarchy of all items is identified through the ranking of their respective mean rank, with consideration for behavioural change at the apex, followed by influencing current positive trends for recycling waste, playing a significant role in reducing waste, increasing recycling, influencing the desire to recycle waste and so on. The mean rank of most items which measure the role of financial incentive for recycling fell below the set midpoint (2.50). This finding infers that the role of financial incentives is indispensable to the sustainable recycling of municipal solid waste. Thus, the debut of financial incentives for the recycling of other municipal solid waste, besides PET bottles and drink cans, is required for boosting consumer participation in the recycling of municipal solid waste. 
Table 2. Perceived role of financial incentives for recycling.

\begin{tabular}{cccccccc}
\hline Roles & $\begin{array}{c}\text { Strongly } \\
\text { Agree }\end{array}$ & Agree & Undecided & Disagree & $\begin{array}{c}\text { Strongly } \\
\text { Disagree }\end{array}$ & $\begin{array}{c}\text { Mean } \\
\text { Rank }\end{array}$ & $\begin{array}{c}\text { Standard } \\
\text { Deviation }\end{array}$ \\
\hline 1 & $14(11.4)$ & $65(52.8)$ & $28(22.8)$ & $15(12.2)$ & $1(0.8)$ & 2.38 & 0.873 \\
2 & $21(17.1)$ & $64(52.0)$ & $26(21.1)$ & $11(9.0)$ & $1(0.8)$ & 2.24 & 0.872 \\
3 & $14(11.4)$ & $77(62.6)$ & $26(21.1)$ & $5(4.1)$ & $1(0.8)$ & 2.20 & 0.724 \\
4 & $24(19.5)$ & $44(35.8)$ & $24(19.5)$ & $30(24.4)$ & $1(0.8)$ & 2.51 & 1.089 \\
5 & $24(19.5)$ & $59(48.0)$ & $21(17.1)$ & $17(13.8)$ & $2(1.6)$ & 2.30 & 0.991 \\
6 & $23(18.7)$ & $65(52.8)$ & $20(16.3)$ & $13(10.6)$ & $2(1.6)$ & 2.22 & 0.919 \\
7 & $12(9.8)$ & $47(38.2)$ & $47(38.2)$ & $15(12.2)$ & $2(1.6)$ & 2.58 & 0.887 \\
8 & $13(10.6)$ & $55(44.7)$ & $40(32.5)$ & $14(11.4)$ & $1(0.8)$ & 2.49 & 0.853 \\
9 & $17(13.8)$ & $50(40.7)$ & $44(35.8)$ & $11(8.9)$ & $1(0.8)$ & 2.42 & 0.868 \\
10 & $17(13.8)$ & $64(52.0)$ & $24(19.5)$ & $16(13.0)$ & $2(1.6)$ & 2.37 & 0.934 \\
11 & $10(8.1)$ & $56(45.5)$ & $39(31.7)$ & $16(13.0)$ & $2(1.6)$ & 2.54 & 0.880 \\
\hline
\end{tabular}

Table 3. Variables and definitions for the perceived role of financial incentives for recycling.

\begin{tabular}{cc}
\hline Variable & Definition \\
\hline 1 & Financial incentive stimulates knowledge for recycling waste. \\
2 & Financial incentive plays a significant role to reduce waste and increase recycling. \\
3 & Financial incentive is a consideration for behavioural change. \\
4 & Financial incentive is a critical motivational factor for recycling. \\
5 & Financial incentive influences the desire to recycle waste. \\
6 & Financial incentive influences current positive trends for recycling waste. \\
7 & Financial incentive is a tangible benefit for recycling waste. \\
8 & Financial incentive is feasible for the goal of recycling waste. \\
9 & Financial incentive is a sustainable approach to recycling waste. \\
10 & Financial incentive promotes awareness of recycling waste. \\
11 & Financial incentive promotes recycling best practices. \\
\hline
\end{tabular}

\subsubsection{Drivers for Recycling}

The results concerning drivers for the recycling of municipal solid waste are shown in Table 4 . See Table 5 for the variables and definitions of the drivers for recycling.

About half of the participants (45.5\%) strongly agreed that they deposit recyclable materials at designated points because of their belief in the benefits of recycling. Meanwhile, $61.8 \%$ of the participants agreed that they deposit recyclable materials at designated points by considering the detrimental environmental impacts of not doing so, while $44.7 \%$ agreed that they deposit recyclable materials at designated points in relation to the extent of information provided. The findings from the survey of consumers on the drivers for the recycling of municipal solid waste indicate that the most important driver is a belief in the benefit of recycling. This is in line with a study reported in Reference [29], in which beliefs about the importance of recycling were positively related to the tendency to recycle. Likewise, the least important driver is related relatively to its attached financial incentives. Ranking the mean rank of all items presents a hierarchy of drivers, with a belief in the benefits of recycling at the pinnacle, followed by consideration of the detrimental environmental impacts, the culture of stewardship, conservation and preservation, value and so on. The mean rank of some drivers for recycling municipal solid waste which fell below 2.50 is found to be an intrinsic factor and vice versa. This infers that consumers' behaviour for recycling is more driven on the basis of socio-psychological factors in the study area. This is supported by the findings from a study on behaviour change in post-consumer recycling, as reported in Reference [30]. This study applied agent-based modelling in a social experiment which identified social norms as a decisive effect, irrespective of whether an area starts recycling or not. 
Table 4. Drivers for recycling.

\begin{tabular}{cccccccc}
\hline Drivers & $\begin{array}{c}\text { Strongly } \\
\text { Agree }\end{array}$ & Agree & Undecided & Disagree & $\begin{array}{c}\text { Strongly } \\
\text { Disagree }\end{array}$ & $\begin{array}{c}\text { Mean } \\
\text { Rank }\end{array}$ & $\begin{array}{c}\text { Standard } \\
\text { Deviation }\end{array}$ \\
\hline 1 & $27(22.0)$ & $76(61.8)$ & $13(10.6)$ & $5(4.1)$ & $2(1.6)$ & 2.02 & 0.799 \\
2 & $21(17.1)$ & $48(39.0)$ & $33(26.8)$ & $17(13.8)$ & $4(3.3)$ & 2.47 & 1.035 \\
3 & $23(18.7)$ & $50(40.7)$ & $28(22.8)$ & $13(10.6)$ & $9(7.3)$ & 2.47 & 1.133 \\
4 & $9(7.3)$ & $37(30.1)$ & $42(34.1)$ & $20(16.3)$ & $15(12.2)$ & 2.96 & 1.119 \\
5 & $22(17.9)$ & $53(43.1)$ & $20(16.3)$ & $15(12.2)$ & $13(10.6)$ & 2.54 & 1.223 \\
6 & $12(9.8)$ & $55(44.7)$ & $38(30.9)$ & $10(8.1)$ & $8(6.5)$ & 2.57 & 1.001 \\
7 & $11(8.9)$ & $53(43.1)$ & $26(21.1)$ & $15(12.2)$ & $18(14.6)$ & 2.80 & 1.212 \\
8 & $56(45.5)$ & $49(39.8)$ & $7(5.7)$ & $8(6.5)$ & $3(2.4)$ & 1.80 & 0.981 \\
\hline
\end{tabular}

Table 5. Variables and definitions for drivers for recycling.

\begin{tabular}{|c|c|}
\hline Variable & Definition \\
\hline 1 & $\begin{array}{c}\text { I drop off recyclable materials at designated points out of consideration of the detrimental } \\
\text { environmental impacts. }\end{array}$ \\
\hline 2 & $\begin{array}{c}\text { I drop off recyclable materials at designated points due to my culture of stewardship, conservation } \\
\text { and preservation. }\end{array}$ \\
\hline 3 & I drop off recyclable materials at designated points because they are valuable. \\
\hline 4 & I drop off recyclable materials at designated points relative to the available financial incentives. \\
\hline 5 & I drop off recyclable materials at designated points due to the closeness of recycling facilities. \\
\hline 6 & I drop off recyclable materials at designated points relative to the extent of information provided. \\
\hline 7 & I drop off recyclable materials at designated points due to stipulated policies and regulations. \\
\hline 8 & I drop off recyclable materials at designated points because of my belief in the benefits of recycling. \\
\hline
\end{tabular}
Percentages are in parentheses.

\subsubsection{Consumers' Recycling Behaviour}

The results concerning consumers' recycling behaviour are shown in Table 6. More than $50 \%$ of the respondents always recycle newspapers $(65.0 \%)$, magazines $(56.9 \%)$, PET plastic bottles $(57.7 \%)$ and glass (52.8\%). The mean rank for all other recyclable materials falls below the set midpoint (2.50), with the exception being tetra packs $(\mathrm{M}=2.68)$. This implies that there is a high tendency towards the recycling of newspapers, mixed papers, magazines, cardboard, glass, PET plastic bottles and metals. The most recycled materials are newspapers $(\mathrm{M}=1.58)$ and the least recycled materials are tetra packs $(M=2.68)$. The disparity in responses about recycling behaviour between other recyclables and tetra packs may be due to convenience and effort involved in folding tetra packs into more compacted forms prior to recycling. Although the results show that there is evidence of recycling among the respondents, the proportion is not as impressive for a developed country with a recycling framework in place for these materials. Therefore, there is a need to encourage more members of the population to recycle materials where there is a recycling channel already in place.

Table 6. Recycling behaviour.

\begin{tabular}{cccccccc}
\hline Materials & Always & Often & Sometime & Rarely & Never & Mean Rank & Standard Deviation \\
\hline Newspapers & $80(65.0)^{*}$ & $27(22)^{*}$ & $8(6.5)^{*}$ & $4(3.3)^{*}$ & $4(3.3)^{*}$ & 1.58 & 0.984 \\
Mixed papers & $47(38.2)^{*}$ & $34(27.6)^{*}$ & $31(25.2 *)$ & $7(5.7)$ & $4(3.3)$ & 2.08 & 1.076 \\
Magazines & $70(56.9)^{*}$ & $26(21.1)^{*}$ & $16(13.0)^{*}$ & $7(5.7)^{*}$ & $4(3.3)^{*}$ & 1.76 & 1.072 \\
Cardboards & $43(35)^{*}$ & $31(25.2)^{*}$ & $30(24.4)^{*}$ & $16(13.0)^{*}$ & $3(2.4)^{*}$ & 2.23 & 1.137 \\
PET plastic bottles & $71(57.7)^{*}$ & $24(19.5)^{*}$ & $13(10.6)^{*}$ & $7(5.7)^{*}$ & $8(6.5)^{*}$ & 1.84 & 1.217 \\
Metals & $52(42.3)^{*}$ & $29(23.6)^{*}$ & $27(22.0)^{*}$ & $9(7.3)^{*}$ & $6(4.9)^{*}$ & 2.09 & 1.174 \\
Glass & $65(52.8)^{*}$ & $21(17.1)^{*}$ & $21(17.1)^{*}$ & $10(8.1)^{*}$ & $6(4.9)^{*}$ & 1.95 & 1.214 \\
Tetra packs & $28(22.8)^{*}$ & $31(25.2)^{*}$ & $30(24.4)^{*}$ & $22(17.9)^{*}$ & $12(9.8)^{*}$ & 2.68 & 1.295 \\
\hline
\end{tabular}

* Percentages are in parentheses. 


\subsection{Inferential Statistics}

\subsubsection{Perceived Role of Financial Incentives for Recycling and Recycling Behaviour}

A Spearman's rank-order correlation (Table 7) was used to investigate the direction and strength of the relationship between consumers' perceived role of financial incentives for recycling and recycling behaviour. The correlation coefficient of -0.066 indicates that a very weak and negative relationship exists between consumers' perceived role of financial incentives for recycling municipal waste and consumers' recycling behaviour. This infers that an increase in the perceived role of financial incentives for recycling municipal solid waste is associated with a decrease in recycling behaviour and vice versa. The $p$-value of 0.470 , compared to an $\alpha$-value of 0.01 , proves that there is no significant relationship between the perceived role of financial incentives for recycling and recycling behaviour since the $p$-value is greater than the $\alpha$-value.

Table 7. Spearman correlation between perceived roles of financial incentives and recycling behaviour.

\begin{tabular}{lcccc}
\hline & & & PRFI & RB \\
\hline Spearman's rho & PRFI & Correlation coefficient & 1.000 & -0.066 \\
& & Sig. (two-tailed) & & 0.470 \\
& & N & 123 & 123 \\
& RB & Correlation coefficient & -0.066 & 1.000 \\
& & Sig. (two-tailed) & 0.470 & \\
& & N & 123 & 123 \\
\hline
\end{tabular}

\subsubsection{Drivers for Recycling and Recycling Behaviour}

A Spearman's rank-order correlation (Table 8) was used to examine the direction and strength of the relationship between drivers for recycling and recycling behaviour. The correlation coefficient of 0.265 show that a weak-to-positive relationship exists between drivers for recycling municipal solid waste and recycling behaviour. This implies that an increase in drivers for recycling municipal solid waste is accompanied by an increase in recycling behaviour; likewise, an increase in recycling behaviour is accompanied by an increase in drivers for recycling municipal solid waste. The $p$-value of 0.003 , as compared to an $\alpha$-value of 0.01 , confirms that there is a significant relationship between drivers for recycling municipal solid waste and recycling behaviour since the $p$-value is less than the $\alpha$-value. This suggests that behavioural change factors for the recycling of municipal solid waste influence consumers' recycling behaviour. Motivation is one of the strongest variables shaping recycling behaviour [31].

Table 8. Spearman correlation between drivers for recycling and recycling behaviour.

\begin{tabular}{lcccc}
\hline & & DFR & RB \\
\hline Spearman's rho & DFR & Correlation coefficient & 1.000 & $0.265^{* *}$ \\
& & Sig. (two-tailed) & & 0.003 \\
& & N & 123 & 123 \\
& RB & Correlation coefficient & $0.265^{* *}$ & 1.000 \\
& & Sig. (two-tailed) & 0.003 & \\
& & N & 123 & 123 \\
\hline
\end{tabular}

** Correlation is significant at the 0.01 level (two-tailed).

\subsubsection{Income-Earning and Non-Income-Earning Consumers}

An independent sample $t$-test (Table 9) was used to compare the means of the perceived role of financial incentives for recycling for two independent groups (income-earning consumers and non-income-earning consumers) in determining whether there is statistical evidence confirming that the associated population means are significantly different. The non-income-earning consumers group 
$(N=61)$ is associated with its mean for the perceived role of financial incentives for recycling $M=2.39$ $(\mathrm{SD}=0.469)$ (see Table 10). By comparison, the income-earning consumers group $(\mathrm{N}=62)$ is associated with its numerically bigger mean for the perceived role of financial incentives for recycling $\mathrm{M}=2.40$ $(\mathrm{SD}=0.627)$. Furthermore, the assumption of the uniformity of variance was tested and satisfied via Levene's F test (Table 9), $\mathrm{F}(121)=3.40, \mathrm{P}=0.68$, at a level of significance of 0.05 (where $p>0.05$ ). The independent sample $t$-test is associated with no statistically significant effect, $\mathrm{t}(121)=-0.123$, $\mathrm{P}=0.90$, at a level of significance of 0.05 (where $p>0.05$ ). Hence, there is no significant difference in the means of the perceived role of financial incentives for recycling for the two groups. This implies that both groups of consumers show an interest in financial incentives. This is line with previous research which found that both non-income-earning consumers and income-earning consumers are very sensitive to economic incentives [32]. Cohen's D was estimated at 0.02 . This infers a small effect according to Cohen's guidelines [33]. The 95\% confidence interval was -0.210 to 0.186 .

Table 9. Independent sample $t$-test for income-earning and non-income-earning consumers.

\begin{tabular}{|c|c|c|c|c|c|c|c|c|c|c|}
\hline & & & & & & & & & $\begin{array}{c}95 \% \\
\text { Confidence } \\
\text { Interval of The } \\
\text { Difference }\end{array}$ & \\
\hline & & $\mathbf{F}$ & Sig. & $\mathbf{t}$ & $\mathrm{df}$ & $\begin{array}{c}\text { Sig. } \\
\text { (Two-Tailed) }\end{array}$ & MD & SE & Lower & Upper \\
\hline GMPRFI & $\begin{array}{c}\text { EVA } \\
\text { EVNA }\end{array}$ & 3.400 & 0.68 & $\begin{array}{l}-0.123 \\
-0.123\end{array}$ & $\begin{array}{c}121 \\
112.944\end{array}$ & $\begin{array}{l}0.903 \\
0.902\end{array}$ & $\begin{array}{l}-0.01227 \\
-0.01227\end{array}$ & $\begin{array}{l}0.09999 \\
0.09976\end{array}$ & $\begin{array}{l}-0.21023 \\
-0.20992\end{array}$ & $\begin{array}{l}0.18569 \\
0.18537\end{array}$ \\
\hline
\end{tabular}

Table 10. Income-earning and non-income-earning consumers.

\begin{tabular}{lcccccc}
\hline & NIAIC & Number & Mean & SD & SEM \\
\hline \multirow{2}{*}{ Group means of the perceived role of FI } & No & 61 & 2.3892 & 0.46901 & 0.06005 \\
& Yes & 62 & 2.4015 & 0.62726 & 0.07966 \\
\hline
\end{tabular}

FI = financial incentive.

\subsection{Cronbach Alpha}

Cronbach alpha is a reliability test which measures the internal consistency of a scale. In particular, it measures the variance of measure for the variance of response in one item with the overall variance [34]. The Cronbach alpha for the perceived role of financial incentives for recycling was 0.834, while that for the drivers for recycling was 0.601 and that for recycling behaviour was 0.817 . The perception that alpha should be greater than 0.7 has been disputed in [35]. This was the case with the Cronbach alpha value of 0.601 for drivers for recycling. The Cronbach alpha values of 0.834 , 0.601 and 0.817 for the perceived role of financial incentives for recycling, drivers for recycling and recycling behaviour, respectively, are indicative of the accuracy of the measures and the elimination of random errors.

\section{Conclusions}

The study examined consumers' perception about the role of financial incentives in effecting the recycling of municipal solid waste materials in Vaasa, Finland. The findings of the study confirm the effectiveness of monetary incentives in promoting recycling.

The empirical results revealed that the role of monetary rewards for municipal solid waste cannot be overemphasized. Thus, financial incentives are prerequisites for attaining the stipulated EU recycling rate for municipal solid waste in Finland. The major driver for the recycling of municipal solid waste is a belief in the benefits of recycling. The minor driver for the recycling of municipal solid waste is relative to its attached financial incentive. With relevance to the aforementioned key factor, it is expected that a strict adherence to and conformity with Finnish waste policies should be aligned 
to EU waste policies, which state that recycled waste intended for material recovery and reuse should not be diverted for energy generation.

The study also found that, although mechanisms already exist for the recycling of some waste materials, including newspapers, magazines, mixed papers, cardboard, PET plastics bottles, metals, glass and tetra packs, the level of participation in the recycling of these materials is barely above the average proportion of the population. Therefore, there is a need to put in place interventions which will increase the participation of many more members of society in the recycling of municipal waste materials, such as tetra packs and glass, which are generated in enormous quantities on a daily basis in Finland. These are used in the package of food and involve a with high daily consumption rate among households. The interventions for promoting an increase in recycling should be anchored to key drivers for recycling. Interventions, drivers and incentives are interrelated, as their goal is geared towards motivating people in the course of events.

Author Contributions: Conceptualization, B.A.; methodology B.A. and J.K.; Formal analysis and investigation, B.A.; Writing—original draft, B.A.; writing—review and editing, B.A.; validation, B.A. and J.K.; supervision, J.K.

Funding: This research was funded by the Evald and Hilda Nissi Foundation, Finland.

Conflicts of Interest: The authors declare no conflicts of interest.

\section{References}

1. Mueller, W. The effectiveness of recycling policy options: Waste diversion or just diversions? Waste Manag. 2013, 33, 508-518. [CrossRef] [PubMed]

2. Troschinetz, A.M.; Mihelcic, J.R. Sustainable recycling of municipal solid waste in developing countries. Waste Manag. 2009, 29, 915-923. [CrossRef] [PubMed]

3. Ruzzin, M. 'Pay-as-you-throw—let's Start Rewarding the Recyclers. 2002. Available online: http://archive. is/gbkbw (accessed on 26 November 2016).

4. European Environmental Agency (EEA). Recycling Rates in Europe. 2013. Available online: http://www.eea.europa.eu/about-us/competitions/waste-smart-competition/recycling-rates-ineurope/image_view_fullscreen (accessed on 3 April 2017).

5. European Commission (EC). Waste-Review of Waste Policy and Legislation. 2016. Available online: http: / / ec.europa.eu/environment/waste/target_review.htm (accessed on 4 April 2017).

6. Dahlbo, H.; Poliakova, V.; Myllari, V.; Sahimaa, O.; Anderson, R. Recycling potential of post-consumer plastic packaging in Finland. Waste Manag. 2018, 71, 52-61. [CrossRef] [PubMed]

7. Statistics Finland. Incineration and Recycling Have Replaced Landfills for Municipal Waste. 2016. Available online: https://www.stat.fi/til/jate/2015/jate_2015_2016-12-20_tie_001_en.html (accessed on 13 December 2018).

8. Statistics Finland. Mining and Construction Increased the Total Amount of Waste in 2016. 2018. Available online: https://www.stat.fi/til/jate/2016/jate_2016_2018-08-31_tie_001_en.html (accessed on 13 December 2018).

9. Abila, B.; Kantola, J. Sustainable waste management in Finland: Applying axiomatic design. In Proceedings of the 11th International Conference on Innovation and Management, Vaasa, Finland, 17-19 November 2014; Yang, L., Kantola, J., Eds.; Wuhan University Press: Wuhan, China, 2014; pp. 66-72.

10. Piippo, S. Municipal solid waste management in Finland. Available online: http://nortech.oulu.fi/ GREENSETTLE_files/Municipal\%20solid\%20waste\%20management\%20in\%20Finland.pdf (accessed on 28 December 2018).

11. Elia, V.; Gnoni, M.G.; Tornese, F. Designing pay-as-you-throw schemes in municipal waste management services: A holistic approach. Waste Manag. 2015, 44, 188-195. [CrossRef] [PubMed]

12. Bilitewski, B. Pay-as-you-throw-A tool for urban waste management. Waste Manag. 2008, 28, 2759. [CrossRef] [PubMed]

13. Reichenbach, J. Status and prospects of pay-as-you-throw in Europe-A review of pilot research and implementation studies. Waste Manag. 2008, 28, 2809-2814. [CrossRef] [PubMed]

14. Wikipedia. Pay as You Throw. Available online: https://en.wikipedia.org/wiki/Pay_as_you_throw (accessed on 16 February 2018). 
15. Skumatz, L.A. Pay as you throw in the US-Implementation, impacts and experience. Waste Manag. 2008, 28, 2778-2785. [CrossRef]

16. Puig-Ventosa, I. Charging systems and PAYT experiences for waste management in Spain. Waste Manag. 2008, 28, 2767-2771. [CrossRef]

17. Puig-Ventosa, I.; Forn, M.C.; Vivanco, D.F. Pay as you throw in Spain-An update on the prospect for pay-as-you-throw waste charges in Spain. Available online: http:/ /www.waste360.com/pay-you-throwpayt/pay-you-throw-spain (accessed on 16 February 2017).

18. Le Bozec, A. The implementation of PAYT system under the condition of financial balance in France. Waste Manag. 2008, 28, 2786-2792. [CrossRef]

19. Dunne, L.; Convery, F.J.; Gallagher, L. An investigation into waste charges in Ireland with emphasis on public acceptability. Waste Manag. 2008, 28, 2826-2834. [CrossRef]

20. Sakai, S.; Ikematsu, T.; Hirai, Y.; Yoshioda, H. Unit-charging programs for municipal solid waste in Japan. Waste Manag. 2008, 28, 2815-2825. [CrossRef] [PubMed]

21. Yau, Y. Domestic waste recycling, collective action and economic incentive-The case in Hong Kong. Waste Manag. 2010, 30, 2440-2447. [CrossRef] [PubMed]

22. Pacheco, E.B.A.V.; Ronchetti, L.M.; Masanet, E. An overview of plastic recycling in Rio de Janeiro. Resour. Conserv. Recycl. 2012, 60, 140-146. [CrossRef]

23. Bor, Y.J.; Chien, Y.; Hsu, E. The market-incentive recycling system for waste packaging containers in Taiwan. Environ. Sci. Policy 2004, 7, 509-523. [CrossRef]

24. Owusu, V.; Adjei-Addo, E.; Sundberg, C. Do economic incentives affect attitudes to solid waste source separation? Evidence from Ghana. Resour. Conserv. Recycl. 2013, 78, 115-123. [CrossRef]

25. Shaw, P.J.; Maynard, S.J. The potential of financial incentives to enhance householders'́ kerbside recycling behaviour. Waste Manag. 2008, 28, 1732-1741. [CrossRef]

26. Härmä, O. Smart Shoppers in Finland: New Shopping Attitude and Response of Retailers. Bachelor's Thesis, University of Applied Science, Vaasa, Finland, 2010.

27. Diah, N.M.; Ismail, M.; Ahmad, S.; Mahmud, M.I. Adaptation of environmental anticipation in educational computer game. Procedia Soc. Behav. Sci. 2012, 42, 74-81. [CrossRef]

28. Maki, A.; Burns, R.J.; Ha, L.; Rothman, A.J. Paying people to protect the environment: A meta-analysis of financial incentive interventions to promote environmental behaviors. J. Environ. Psychol. 2016, 47, 242-255. [CrossRef]

29. Latif, S.A.; Omar, M.S.; Bidin, Y.H.; Zainudin, A. Environmental values as a predictor of recycling behavior in urban areas: A comparative study. Procedia Soc. Behav. Sci. 2012, 50, 989-996. [CrossRef]

30. Tong, X.; Nicilic, I.; Dijkuizen, B.; Hoven, M.; Minderhoud, M.; Wäckerlin, N.; Wang, T.; Tao, T. Behaviour change in post-consumer recycling: Applying agent-based modeling in social experiment. J. Clean. Prod. 2018, 187, 1006-1013. [CrossRef]

31. Bom, U.B.; Belbase, S.; Lila, R.B. Public perceptions and practices of solid waste recycling in the city of Laramie in Wyoming, U.S.A. Recycling 2017, 2, 11. [CrossRef]

32. Crociata, A.; Agovino, M.; Sacco, P.L. Recycling waste: Does culture matter? J. Behav. Exp. Econ. 2015, 55, 40-47. [CrossRef]

33. Cohen, J. A power primer. Psychol. Bull. 1992, 112, 115-159. [CrossRef]

34. Maughan, E.D. Validity and reliability: What do these terms mean? NANS School Nurse 2009, 24, 119-120. [CrossRef] [PubMed]

35. McCrae, R.R.; Kurtz, J.E.; Yamagata, S.; Terracciano, A. Internal consistency, retest reliability and their implications for personality scale validity. Pers. Soc. Psychol. Rev. 2011, 15, 28-50. [CrossRef] [PubMed]

(C) 2019 by the authors. Licensee MDPI, Basel, Switzerland. This article is an open access article distributed under the terms and conditions of the Creative Commons Attribution (CC BY) license (http:/ / creativecommons.org/licenses/by/4.0/). 